\title{
The Effect of Avocado's (Persea Americana) Ethanolic Extract for Increasing Macrophages Cells in Rattus Norvegicus Post Extraction Socket
}

\author{
Delvi Fitriani \\ Department of Dentistry Material Science \\ Faculty of Dentistry, Universitas Brawijaya \\ Malang, Indonesia
}

\author{
Nenny Prasetyaningrum \\ Department of Oral Biology \\ Faculty of Dentistry, Universitas Brawijaya \\ Malang, Indonesia
}

\author{
Sinta Gitaning Rahayu \\ Student \\ Faculty of Dentistry, Universitas Brawijaya \\ Malang, Indonesia
}

\begin{abstract}
Tooth extraction is always followed by wound healing process. Macrophage plays role as a phagocytosis cells, inducing granulation tissue formation, reepitelisation and angiogenesis process. Avocado (Persea americana) is a tropical fruits due to flavonoids contained has many benefits like provide immunostimulatory effects so that it will increase macrophage activation. The purpose of this research was determined the effect of avocado ethanolic extract for increasing macrophages cells after tooth extraction in Rattus norvegicus. This research was using randomized post-test only control group design method. Twenty four rats had tooth extracted. They were divided into 4 groups $(K, P 1, P 2$ and $P 3)$. In group $K$, subjects were not given avocado extract (control positive groups), group $P 1$ were given $150 \mathrm{mg} /$ weight/day, group $P 2 \quad 300 \mathrm{mg} /$ weight/day and groups IV $450 \mathrm{mg} /$ weight/day orally for 3 and 7 days. The number of macrophages in rat's socket was determined by histological preparations with HE staining using a light microscope. As a result, the statistical test in day-3 showed differences in the number of macrophages cells between group (ANOVA, $p=0,000)$ and positive correlation between the dose of the avocado extract with macrophage cells number $(r=0,684)$. In day-7 showed differences between groups (Krusskal-Wallis, $p=0,969$ ) but negative correlation between the dose of the avocado extract with the number of macrophages cells $(r=\mathbf{- 0 , 0 4 3})$. Conclusion : The avocado extract increased macrophage cells in rat's socket on day-3 in all doses but decreased on day-7 after tooth extraction.
\end{abstract}

Keywords-avocado (Persea americana), macrophages, tooth extraction, wound healing

\section{INTRODUCTION}

Injury is often associated with tooth extraction in dentistry. Tooth extractions procedure caused a wound that is always followed by the wound healing process [1]. This process is important to prevent infection as tissues respond to trauma. Wound healing is restoration process of tissue integrities, structures and functions [2]. One of the most important cell in wound healing process is the macrophage $[3,4]$.

Macrophage is inflammatory cell with giant form of nucleus and foamy appearance in histological aspect. Macrophage appears $24-48$ hours right after trauma and reach its peak level at third day. The macrophage function is to phagocyte, synthesize collagen, forming granulation tissue with fibroblasts, producing growth factor (VEG, EGF, TGF- $\alpha$, TGF- $\beta 1$, PDGF and FGF) that contribute to reepitelization and angiogenesis [3,5].

In tropical countries like Indonesia, avocado plants (Persea americana) are easy to find and can be used as natural remedies [7]. The avocado fruits could be used to overcome stomatitis and mosturize the skin, the seeds could relieve toothache and beneficial for patient with diabetes mellitus, while the leaves could be used to relieve headache and nerve pain. Avocado contains saponins, alkaloids, and flavonoid as the highest content [6].

Extract of natural remedies which contain saponins, flavonoids, essential oils, proteins, and vitamin $\mathrm{C}$ are known could increasing wound healing process [6]. Flavonoids as immunostimulant could increased the activation of macrophage so that it could be assumed by the administration avocado extract after tooth extraction could increasing the number of macrophage in the tooth socket [7]. The high level of macrophage could increase the growth factors in inflamation which means more new cells and tissue granulation formed so that fasten the wound healing process $[12,13]$.

The aims of this research is to determine the effect of avocado extract (Persea americana) on the number of macrophage cells in the wound healing process postextraction of Rattus norvegicus.

The benefit of this research in the dentistry is to increase knowledge about alternative herbal treatment 
to accelerate the process of wound healing after tooth extraction.

\section{MATERIALS AND METHODS}

The research was an experimental research using Randomized Post Test Only Control Group Design, where subjects were divided into 4 groups (K, P1, P2 and P3) randomly and the it was done with 2 time series, the 3rd day and the 7th day of observation. Group $\mathrm{K}$ was the positive control group and the P1, P2 and P3 groups as the treatment group with the administration of avocado extract (Persea americana) at consecutive doses of $150 \mathrm{mg}, 300 \mathrm{mg}$ and $450 \mathrm{mg}$ per $\mathrm{kg}$ body weight of the mice.

The experimental animal population in this study was male Rattus norvegicus Wistar strain. Sample was taken by Randomized Complete Design. The inclusive criteria were the clear eyes Wistar strain Rattus norvegicus, white fur, and active moves. The exclusive criteria were blind rats, non white fur and non active or die rats.

The variable of this experiment is avocado extract (Persea americana) as dependent variable and the number of macrophage as independent variable.

The research was conducted in Pharmacology Laboratory and Histology Laboratory of Faculty of Medicine Universitas Brawijaya Malang within three months (December 2013-March 2014).

Overall materials and tools used during the study include comfeed animal feed, water taps, $40 \mathrm{ml} / \mathrm{kgBW}$ ketamine anesthesia, lethal dose ether, EDTA 14\%, $10 \%$ formalin solution, $5 \% \mathrm{HCL}, 1 \%$ ammonium oxalate, alcohol 70\%, 80\%, 95\% and 96\%, 96\% alcohol + prusi, xylol and paraffin, hematoxylin, water, eosin and canals balsam, aquades, filter paper, avocado fruits (Persea americana), masks, gloves, 8 plastic boxes $15 \times 30 \times 42 \mathrm{~cm} 3$, wire boxs caps, husks as base boxes, drinking pot, Sartorius brand of ohaus balance for weighing rats, knives, mortar and pastels, water bath, analytic balance , filter paper, $250 \mathrm{ml}$ beaker glass, soxhlet extractor tube, and rotary evaporator vacuum, modified needle holder, modified lecron, cotton, saucer, $2.5 \mathrm{ml}$ injection syringe and gastric spoon, scalpel no. 11, tweezers, surgical scissors, and labeled fixation tubes, rotary microtome, oven, object glass, cover glass, light microscope, and digital camera for histologic photographs.

The animals were selected based on the sample criteria, then divided into 4 groups, each consisting of 6 rats preserved in the preservation of experimental animal. Rats were kept and adapted in the cages in laboratory for 1 week at a constant room temperature $\left(20-25^{\circ} \mathrm{C}\right)$ with 12 hours of light-dark cycle. The preservation cages was $15 \times 30 \times 42 \mathrm{~cm}^{3}$ plastic boxes with husk and covered with wire netting, each for 3 rats. The adult rats need 50 gr of food everyday.

The avocado extract was made using soxhlet process. The dose range used was taken from previous study [12], which examined the wound healing of the external skin wound of $300 \mathrm{mg} / \mathrm{kgBW}$ so the estimate dose for this experiment was dose I (150 mg/ $\mathrm{kgBW})$, dose II ( $300 \mathrm{mg} / \mathrm{kgBW}$ ) and dose III (450 mg/kgBW).

Before extraction of mandibular right incisors, each rats was given anesthesia with ketamine $40 \mathrm{ml} / \mathrm{KgBB}$ intra-muscularly so that the mice became unconscious. The rat's teeth were extracted using a modified forcep for rat then sutured. Rats are given enough food and water to keep the animals healthy.

Avocado extract is administered once daily orally after 3 to 7 days of tooth extraction. Administration of treatment group I $(150 \mathrm{mg} / \mathrm{KgW} /$ day $), \quad$ II (300 $\mathrm{mg} / \mathrm{KgW} /$ day), and III (450 mg/KgW/day) using gastric sonde technique into the mouth of rats up to the stomach. The administration were $1 \mathrm{ml}$ once per day.

There was different way of feeding the rat before and after extraction to avoid wound healing disturbances and pain in socket caused by the food. Before extraction, rats were given food without dilution, while after the extraction the food were diluted and given orally by gastric sonde directly to the stomach. Feeding was done routinely and water were given sufficiently.

Rats euthanasia were performed in each group using inhaled lethal dose ether placed on cotton, then cotton and rats were put into the jar so that the mice become unconscious. The rats were slaughtered using scalpel no. 11 and the lower jaw where a tooth has been removed were taken. The lower jaw of the rats were put into a labeled tube containing $10 \%$ formalin for 24 hours. The sample were rainsed in running water and then decalcified with EDTA $14 \%$ for 30 days until the mandibular bone tissue become soft and can be cut into small rectangles. Then, the processing technique of tissue were carried out which is fixation, dehydration, clearing and impregnation. The histological speciment then made and finished with hematoxylen eosin staining.

Data were made on the histologic preparations in 3rd and 7th days observation using a light microscope with 400x magnification. Calculation of macrophage cells then performed at 10 fields around socket.

\section{RESULTS}

The result of cell count of rats macrophage in positive control and treatment groups were as the following below.

Based on data, the number of macrophage cells increased on the $3^{\text {rd }}$ day and decreased on the $7^{\text {th }}$ day observation. Data analysis used for the 3rd day was the ANOVA Oneway statistical test due to the normal distribution data and Krusskal-Wallis test for $7^{\text {th }}$ day observation due to abnormal data distribution. Observation on day 3 and 7 analysis of the difference in cell macrophages between groups using the Post Hoc Multiple Comparison analysis with the method used was the Tukey test. In this test we got $p$ value $<0,05$ on day 3 and $p>0,05$ on day 7 . So it can be concluded on the 3rd day there is a significant difference in the number of macrophage cells in the Rattus norvegicus socket between the two groups, whereas on day 7 there 
is no significant difference in the number of macrophage cells in the Rattus norvegicus socket between the two groups.

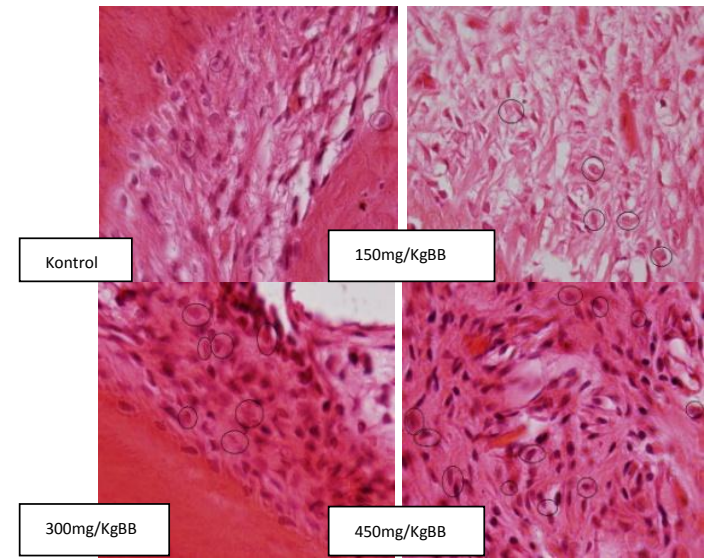

Figure 1. Histologic image of rats socket with HE staining, 400x magnification using light microscope on day $3^{\text {rd }}$. The number of macrophages increased in all doses.

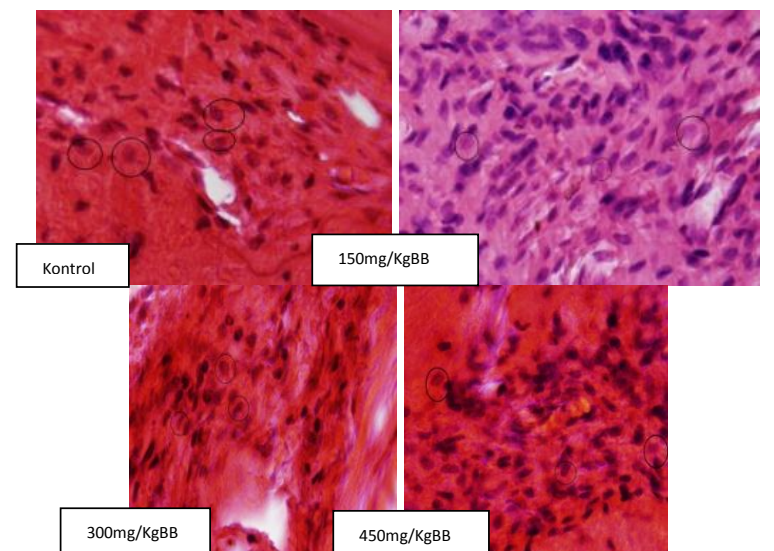

Figure 2. Histologic image of rats socket with HE staining, 400x magnification using light microscope on day 7 th. The number of macrophages decreased in all dose.

Penghitungan Rerata Sel Makrofag

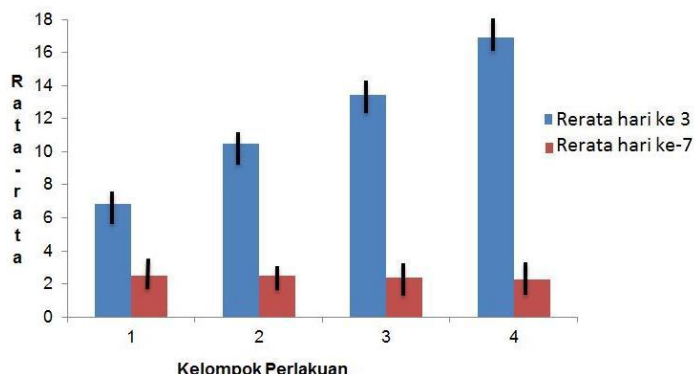

Figure 3. The diagram of Cell Calculation Chart of Macrophage Rat Rattus norvegicus on day 3rd and 7th on Microscopic Inspection 400x Enlargement per 10 Field Places. Information: (1) Tooth extraction without the granting of avocado (Persea americana) $=$ Po, (2) Tooth extraction by graft avocado (Persea americana) $150 \mathrm{mg} / \mathrm{KgBB}=\mathrm{P} 1$, (3) Tooth extraction by granting avocado (Persea americana) $300 \mathrm{mg} / \mathrm{KgBB}=\mathrm{P} 2$, (4) Tooth extraction by granting avocado (Persea americana) $450 \mathrm{mg} / \mathrm{KgBB}=\mathrm{P} 3$

After the Person correlation test was performed to measure the strength of the relationship between two or more variables (parameters) which is on day 3 , the
Spearman's rho test is measured the strength of two or more non-parametric-scale relationships on the 7th day. Person Correlation Test and Spearman's rho were used to prove the correlation between the dose of avocado extract (Persea americana) against the number of macrophage cells. On the Person Correlation test, the 3rd day data correlation strength $(r)=0.835$, thus a strong correlation between the dose of avocado extract with the number of rat sockets macrophages of Rattus novergicus. The direction of the 3rd day correlation was positive, so the greater the dose of avocado extract, the greater the number of rat sockets macrophages Rattus novergicus. For Spearman's rho test the results of the 7 th day data correlation strength $(r)=-0.043$ thus a weak correlation between the dose of avocado extract with the number of rat sockets macrophages Rattus novergicus. The direction of the 7 th day correlation is negative, so the greater the dose of avocado extract, the smaller the macrophage number of rat sockets Rattus norvegicus.

\section{DISCUSSION}

Observation on the day 3 in Rattus norvegicus treatment group, the number of macrophage cells were found increased after tooth extraction compared with the control group. The greater the dose of avocado (Persea americana) extract given, the more of macrophage cells found in the rats sockets.

This phenomenon can be explained according to Yoshiyuki study which states that in rats tooth socket after extraction will undergo an inflammatory process resulting in an increase of macrophage cells number [10]. Macrophages are one of the chronic inflammatory cells. Aside from being a phagocyte cell, macrophages also serve as a major source of healing mediators. After being activated macrophages release growth factors and cytokines (TGF- $\alpha$, TGF- $\beta 1$, PDGF, insulin-like growth factor [IGF] -I and -II, TNF- $\alpha$, and IL-1) in the wound area. This will further strengthen and prolong the action of chemical mediators and cell mediators released previously by degranulated thrombocytes and neutrophils $[3,10]$.

Macrophages affect all phases early in wound healing by regulating local tissue remodeling by proteolytic enzymes (e.g., collagenase matrix and matrix metalloproteases), forming new extracellular matrices and modulation of angiogenesis and fibroplasia through local production of cytokines, such as thrombospondin-1 and IL-1b [4,13]. Increased activation of macrophages can be done by administering immunostimulants [13]. The results of phytochemical tests of avocados contain saponins, tannins, flavonoids, Cyanogenic glycosides, alkaloids, phenols and steroids [6]. Flavonoids are the most content in avocado fruit. Flavonoids may have an immunostimulants effect on macrophage cells [6]. In addition, flavonoids have lipophilic properties that can damage the microbial membranes [15].

Flavonoids present in plants can increase IL-2 activity and lymphocyte proliferation. Lymphocyte 
proliferation affects CD4 + cells, then causes Thl cells to be activated. Activated THL cells affect the SMAF, which includes IFN- $\gamma$ molecules that can activate macrophages, so macrophages have metabolic, motility and phagocytic activity quick and efficient in killing bacteria or microorganism $[2,8]$.

The high number of macrophages significantly for day 3 indicates an increase in phagocytic processes against bacterial and damaged cells (debris) so that the wound cleansing in this group progresses faster. This is consistent with the hypothesis that the avocado extract (Persea americana) can increase the number of Rattus norvegicus postoperative sad macrophage cells.

On day 7 there was a decrease in the number of macrophage cells in the Rattus norvegicus tooth sockets given avocado extract (Persea americana) at all doses. The greater the dose of avocado extract (Persea americana) given, the smaller the number of macrophage cells in rat sockets Rattus norvegicus. This phenomena caused by several factors. The inflammatory process in this phase has been completed, which indicates the acceleration of wound healing process. The wound healing phase of the inflammatory stage is characterized by a reparative response of the body and usually lasts for 3 to 5 days [3].

The gradual decrease in the number of macrophage cells was because of apoptosis (programmed cells death) stage so that the role of macrophages was no longer needed in the next phase, which is the proliferation phase. The role of macrophages in proliferation phase has been replaced by fibroblasts, which was influenced by growth factors that had been produced by macrophages such as PDGF, FGF, TGF- $\beta$ and EGF [13]. The proliferation phase occurs on the 7th day until the 14th post-extraction of the tooth. After that there will be continuous improvement until the structure will return to normal. This process of tissue repair is called the process of reepithelization where wound repair involves mobilization, migration, mitosis and epithelial cell differentiation. Reepithelization will occur through the movement of epithelial cells from the edge of the free network to the damaged tissue $[3,5,14]$. The faster the process of reepithelization will occur the faster the wound closed so the faster the wound healing process $[3,9]$.

As a conclusion, avocado extract (Persea americana) has an effect on the increasing macrophage cell of Rattus norvegicus post extraction socket. Observation on the 3rd day shows the higher dose of avocado extract (Persea americana) given, the more number of macrophage cells of Rattus norvegicus post extraction socket. While the observation on the $7^{\text {th }}$ day shows the higher dose of avocado extract (Persea americana) given, the less number of macrophage cells of Rattus norvegicus post extraction socket.

\section{ACKNOWLEDGMENT}

Acknowledgments are addressed to the Minister of Research, Technology and Higher Education of Indonesia, at the expense of this study was derived from
DRPM Directorate General of Strengthening Risbang in 2017.

\section{REFERENCES}

[1] Samsuhidayat, WM de Jong. Buku ajar ilmu bedah. Jakarta: EGC, 2005, pp. 5-7, 72-73.

[2] B.S. Nayak, S.S. Raju, A.V.C. Rao, "Wound healing activity of Persea americana (avocado) fruit: a preclinical study on rats," vol. 17(3), 2008.

[3] L.J. Peterson, Peterson's principle of oral and Maxillofacial Surgery, $2^{\text {nd }}$ ed., London: BC Decker Inc Hamilton, Larry J. 2004, pp. 18-23.

[4] A.B. Mast AB, Normal wound healing. In: B.M. Achauer, E. Eriksson, eds. Plastic surgery, indication, operation and outcome. Mosby Inc, 2009, pp. 37-53.

[5] V. Kumar, A.K. Abbas, N. Fausto. Robbins and cotran pathologic basis of disease. $7^{\text {th }}$ ed., Philadelphia: Elsevier Saunders, 2005, pp. 107-114.

[6] U. Arukwe, B.A. Amadi, M.K.C. Duru, E.N. Agomuo, E.A. Adindu, P.C. Odika, K.C. Catfish, L. Egejuru, J. Anudike, "Chemical composition of persea americana leaf, fruit and seed," vol. 11(2), 2012

[7] P.N. Sudarsono, D. Gunawan, S. Wahyuono, I.A. Donatus, Purnomo. Medicinal plant II (research result of use) Yogyakarta: Center for Traditional Medicine Studies. UGM, 2002, pp: 85-89.

[8] A. Adityatama, E. Arijani, A. Irmawati, "Increasing number of macrophages on the wound healing process after marmut's tooth extraction (cavia cobaya) due to the provision of meniran extract gel (phyllanthus niruri lynn)," pp. 1-4, 2002

[9] B. Febram, I. Wientarsih, B. Pontjo, "Activity of zalf preparation of banana tree (musa paradisiaca var sapientum) extract in wound healing process in mice (mus musculus albinus)," Traditional Medicine Magazine, vol. 15(3), pp. 121 137, 2010.

[10] K. Yoshiyuki, S. Mario, K. Kazuhiro, S. Masahiro, "Effect of gingseng saponin isolated from red gingseng roots on burn wound healing in mice," British Journal of Pharmacology, vol. 45(20), pp. 467-70, 2006

[11] U. Ukhrowi, The effect of ethanolic extract of upas bidara bulb (merremia mammosa) upon fagocytosis on macrophage and production of nitrite oxide (NO) macrophage study on balb/c mice infected with salmonella typhimurium. Thesis, Postgraduate Program, Diponegoro University, Semarang, 2011.

[12] Akrom, Effect of meniran herba ethanol extract (phyllanthus niruri L.) on cellular immune response of plasmodium berghei swiss infected male mice: Study of phytochemical immunodulation, Thesis, Postgraduate Program of Gadjah Mada University, Yogyakarta, 2004.

[13] K.S. Midwood, L.V. Wiliam, J.T. Schwarzbauer, "Tissue Repair and Dynamics Of The Extracellular Matrix," Int. J. Biochem. Cell. Biol., vol. 36(6), pp. 1031-1037, 2004.

[14] R.F. Diegelmann, M.C. Evans. Wound healing: An overview of acute, fibrotic, and delayed healing," Frontiers in Bioscience, vol. 9, pp. 283-289, 2004

[15] Sukadana, "Antibacterial compound of flavonoid fruit from sweet star fruits (averrhoa carambola linn. L)," Chemical Journal, vol. 3(2), pp. 1009-1011, July 2009 